\title{
Experimental assessment of lionfish removals to mitigate reef fish community shifts on northern Gulf of Mexico artificial reefs
}

\author{
Kristen A. Dahl ${ }^{1}$, William F. Patterson $\mathrm{III}^{1}{ }^{1}$, Richard A. Snyder ${ }^{2,3}$ \\ ${ }^{1}$ University of South Alabama, Dauphin Island Sea Lab, 101 Bienville Blvd, Dauphin Island, AL 36528, USA \\ ${ }^{2}$ University of West Florida, 100 University Parkway, Pensacola, Florida 32514, USA \\ ${ }^{3}$ Present address: Eastern Shore Laboratory, Virginia Institute of Marine Science, Wachapreague, VA 23410, USA
}

\begin{abstract}
Substantial declines in reef fishes were observed at northern Gulf of Mexico artificial reef sites between 2009-2010 and 2011-2012, a period that bracketed the appearance of invasive lionfish in this ecosystem. Small demersal reef fishes, the predominant prey of lionfish in other systems, displayed the greatest declines. However, a confounding factor during this time was the Deepwater Horizon Oil Spill (DWH) in summer 2010. In some areas, targeted lionfish removals have been demonstrated to mitigate negative effects on native fishes. Therefore, we conducted a $2 \mathrm{yr}$ experiment to examine the effectiveness and ecological benefits of targeted lionfish removals at artificial reefs $(n=27)$ off northwest Florida, USA, where lionfish densities reached the highest recorded in the western Atlantic by 2013. All lionfish were removed via spearfishing from 17 reefs in December 2013, 9 of which were periodically re-cleared of lionfish through May 2015. Remaining sites served as uncleared controls. Both juvenile and adult lionfish quickly recruited to cleared reefs, with lionfish reaching pre-clearance densities in $<1 \mathrm{yr}$ on reefs cleared only once. Removal treatment significantly affected reef fish community structure at experimental reefs, but removal effort was insufficient to achieve substantial gains for most taxa, and declines in several taxa were observed throughout, regardless of treatment. It is unclear whether chronic effects of the DWH or regionally high lionfish densities were more important factors in explaining trends observed in reef fish communities, but small-scale targeted lionfish removal efforts had few positive impacts overall on native reef fish communities in this study.
\end{abstract}

KEY WORDS: Lionfish $\cdot$ Reef fish $\cdot$ Invasive species $\cdot$ Gulf of Mexico

\section{INTRODUCTION}

Indo-Pacific lionfishes, Pterois volitans/miles complex (hereafter 'lionfish'), have exhibited an extensive and rapid invasion in the western Atlantic Ocean, thus earning the species the distinction of being the most successful marine fish invader to date (Whitfield et al. 2002, Morris \& Akins 2009, Albins 2013). Lionfish are so abundant and broadly distributed in their invaded range that their eradication is thought to be unachievable (Côté et al. 2013). At the

*Corresponding author: kdahl@disl.org

${ }^{\dagger}$ Corrections to errors by the publisher were made after publication. This version: November 7, 2016. time of this writing, lionfish have established an invaded range of over 7 million $\mathrm{km}^{2}$, in diverse habitat types beyond their native coral reefs across tropical and sub-tropical western Atlantic Ocean waters, including the Caribbean Sea and Gulf of Mexico (GOM) (Schofield 2009, Côté et al. 2013, Schofield et al. 2014).

The GOM is the most recently invaded basin, where lionfish were first reported in 2009 off the northern Yucatan Peninsula, Mexico (Aguilar-Perera \& Tuz-Sulub 2010), in the Florida Keys, USA (Rutten-

() The authors 2016. Open Access under Creative Commons by Attribution Licence. Use, distribution and reproduction are unrestricted. Authors and original publication must be credited. 
berg et al. 2012), and along the west Florida shelf (Schofield 2010). By late 2010, lionfish had been observed in eastern, northern and western regions of the GOM (Schofield 2010, Fogg et al. 2013, Dahl \& Patterson 2014, Nuttall et al. 2014). In the short span of time since initial observations, lionfish populations in the northern GOM (nGOM) have increased exponentially and have reached high densities (>20 fish $100 \mathrm{~m}^{-2}$ ) on artificial reefs, yet their densities on natural reefs remain 2 orders of magnitude lower (Dahl \& Patterson 2014).

The first sightings of lionfish in the nGOM coincided with another significant event in the region: the Deepwater Horizon Oil Spill (DWH). The spill released more than 200 million gallons $\left(\sim 7.6 \times 10^{8} \mathrm{l}\right)$ of oil over several months beginning in April 2010. Effects of the DWH on various biological communities have been documented, yet it is unclear how resilient the nGOM ecosystem will be to this largescale disturbance (Graham et al. 2010, DeLaune \& Wright 2011, Williams et al. 2011, Whitehead et al. 2012). Among reef fishes, reported DWH impacts include changes in diet and trophic position (Tarnecki \& Patterson 2015, Norberg 2015), and shifts in community structure (NOAA-NRDA 2015) following exposure to toxic petroleum compounds (Murawski et al. 2014). Recent ecosystem modeling simulations have indicated that depleted reef fish stocks in the region could have contributed to the rapid increase in lionfish density and biomass (Chagaris et al. 2015). While the DWH may not be the singular factor initiating fish declines, the negative effects of disturbance on native reef fish communities may have similarly increased the system's vulnerability to lionfish invasion.

While the full extent of chronic impacts of the DWH on reef fishes in the nGOM remains unclear, the literature on invasive lionfish in the western Atlantic suggests they pose a clear long-term threat to nGOM reef fishes. Lionfish impacts on native communities have been reported from invaded regions, with a consensus that lionfish alter reef fish community and trophic structure in regions where they have become abundant (Lesser \& Slattery 2011, Albins \& Hixon 2013, Albins 2015). Lionfish are novel predators that consume a broad range of fish and invertebrate prey (Albins \& Hixon 2008, Morris \& Akins 2009, Muñoz et al. 2011), including the juvenile stages of ecologically and economically important fishes (Lesser \& Slattery 2011, Dahl \& Patterson 2014). Lionfish predation has caused substantial declines in the abundances of small adult reef fishes, as well as juvenile recruits of larger reef fish species (Albins \& Hixon 2008, Green et al. 2012, Albins 2015, Benkwitt 2015). Further- more, lionfish have caused significant and rapid declines in prey fish biomass (Green et al. 2012) and species richness (Albins 2013) following their arrival on both continuous reefs and patch reefs. Native predator-prey dynamics may also be destabilized in the presence of lionfish (Ingeman \& Webster 2015), where the invaders can cause nearly 3 -fold greater prey mortality when compared with native mesopredators (Albins 2013). Larger native reef fish species may also be affected via indirect processes such as competition for resources. Dietary overlap of lionfish with native mesopredators, or even apex predators, may lead to decreases in the abundances of those species (Layman \& Allgeier 2012). Predation by and lack of predation on lionfish ultimately results in the diversion of resources from higher trophic levels to an energetic dead end. Additionally, lionfish may alter the behavior of native reef fish and invertebrates via competition for space and shelter (CurtisQuick et al. 2014, Raymond et al. 2015).

The speed of the lionfish invasion coupled with negative impacts to recipient ecosystems has motivated researchers to work towards developing best management practices to mitigate impacts to native communities. There is consensus among researchers and managers that lionfish control is desirable to mitigate their negative effects on marine ecosystems and economies, given that lionfish are now considered to be permanent members of western Atlantic fish communities (Morris \& Whitfield 2009, Arias-González et al. 2011). However, the potential benefits as well as the costs of targeted lionfish removal programs remain unclear. All lionfish management strategies hinge on the goal of a reduction of lionfish populations and thus their corresponding impacts. Targeted removals of lionfish have gained considerable attention in recent years and in some cases have reduced both the numbers and mean size of individuals (Frazer et al. 2012, de León et al. 2013). However, lionfish populations have shown an ability to recover quickly from removal efforts, requiring repeated and substantial harvesting effort to maintain low abundances (AriasGonzález et al. 2011, Barbour et al. 2011). Partial culling has been effective in some cases for stopping the loss of native prey fish biomass with lower effort than would be required for complete lionfish removal (Green et al. 2014). However, other cases have reported that all lionfish must be removed to see substantial conservation gains (Benkwitt 2015). Promotion of the species as a food fish is also gaining popularity and could be a way to increase the geographical scale of lionfish removals (Ferguson \& Akins 2010, Morris et al. 2011b, Côté et al. 2013). 
Here, we report results of a lionfish removal experiment conducted at artificial reef sites in the nGOM. The objectives of the study were to evaluate the effectiveness of targeted lionfish removals as a means to control lionfish densities, as well as to evaluate the effectiveness of lionfish removal for native reef fish community recovery. Pre-invasion community structure data enabled us to examine shifts in native reef fish communities that occurred after lionfish were observed on study reefs in 2010, and then to examine whether lionfish removal efforts facilitated recovery of native fishes. However, the occurrence of the DWH in 2010 presented a confounding factor for initial changes in reef fish communities, and also patterns seen in reef fish communities following lionfish removals. Therefore, we interpret study results with respect to experimental treatments, as well as within the context of potential effects of the DWH on nGOM reef fishes.

\section{MATERIALS AND METHODS}

\section{Study region and experimental reefs}

Study sites consisted of 27 artificial reefs within the Escambia East-Large Area Artificial Reef Site (EELAARS; $260 \mathrm{~km}^{2}$ ), which is located approximately $32 \mathrm{~km}$ south of Pensacola, FL, USA (Fig. 1). The same reefs were used for both the observational and the experimental component of this study. Reefs were originally deployed on the seabed (depth range 27-41 m) by the Florida Fish and Wildlife Conservation Commission in 2003 and consist of 3 different design types: single pyramid, paired tetrahedrons, and paired cylinders with rounded tops (Dance et al. 2011). The composition of all reefs was principally concrete, although pyramid reefs had sides composed of steel rebar in a lattice configuration. Reef volume ranged from 4.09 to $5.68 \mathrm{~m}^{3}$.

Three reefs of each design type were randomly selected for inclusion in one of 2 lionfish removal treatments or a control group during the removal experiment. Nine reefs were selected for a single lionfish removal event (clear-once treatment) in early 2014, and 9 additional reefs were selected to be repeatedly cleared of lionfish via triannual removal events (maintain-clear treatment) through May 2015. The remaining 9 sites were selected for a control treatment with no lionfish removed over the study. However, one of the clear-once reefs was mistakenly not cleared of lionfish in winter 2014; thus, there was one more control reef $(\mathrm{n}=10)$, and one less clear-once site $(\mathrm{n}=8)$, than originally planned.

\section{ROV video sampling and analysis}

We sampled study reefs with a VideoRay Pro4 remotely operated vehicle (ROV) to estimate reef fish community structure for both components of the study, albeit on different time scales. Video sampling
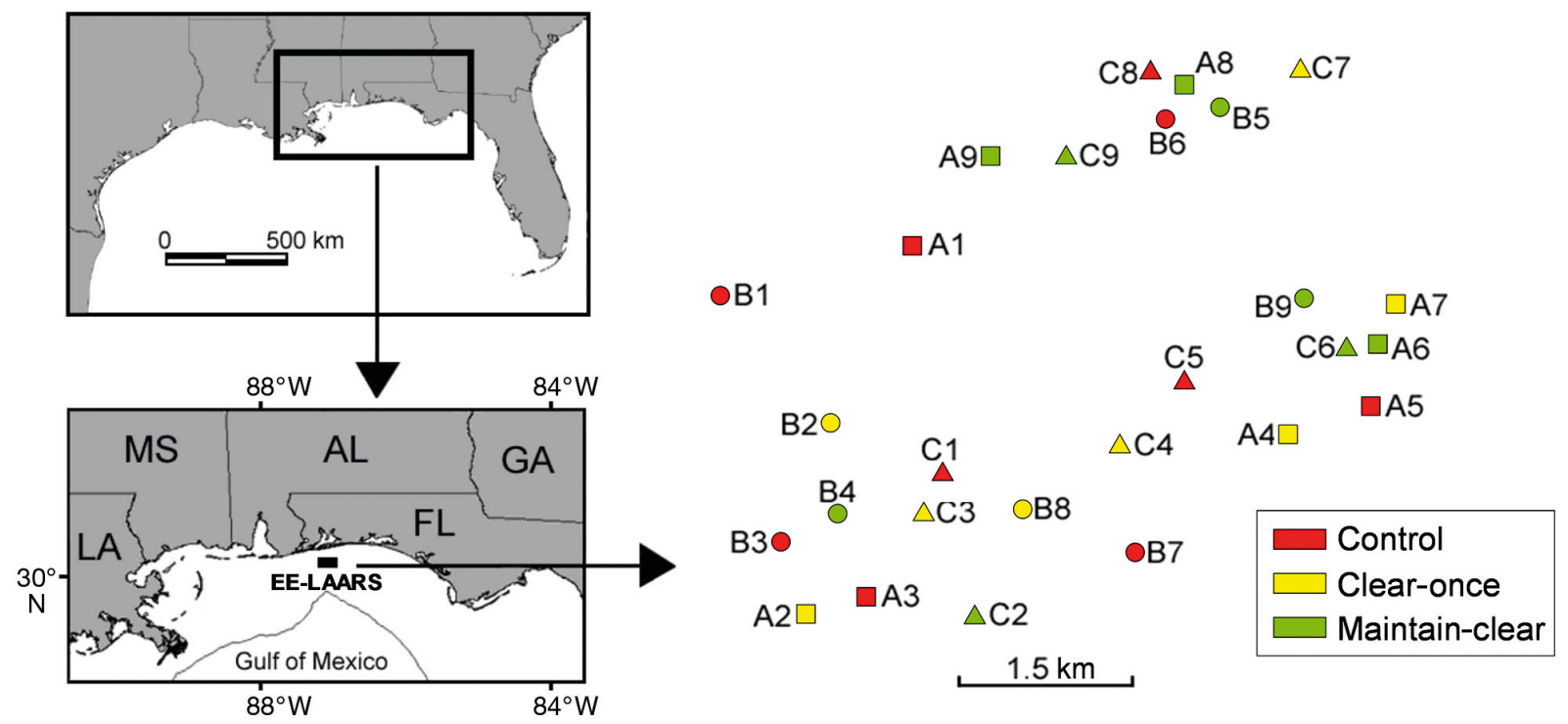

Fig. 1. Map of the northern Gulf of Mexico indicating the locations of the Escambia East-Large Area Artificial Reef Site (EE-LAARS) and the 27 experimental reefs examined in the current study. Experimental reefs were located in the northeast quadrant of the $260 \mathrm{~km}^{2}$ area. Symbols denote different reef types: triangles (paired cylinders with rounded tops), circles (paired tetrahedrons) and squares (single pyramid) 
was conducted quarterly in 2009-2010, which provided baseline data on reef fish community structure prior to lionfish being observed in the nGOM, and again in 2011-2012, the year following the start of the lionfish invasion. During the removal experiment, we conducted triannual (i.e. approx. every $4 \mathrm{mo}$ ) video sampling from December 2013 through August 2015. Specifically, ROV sampling for the removal experiment was performed in December 2013 (fall 2013), March 2014 (spring 2014), July 2014 (summer 2014), December 2014 (fall 2014), May 2015 (spring 2015), and August 2015 (summer 2015).

The VideoRay Pro4 ROV (dimensions: $36 \mathrm{~cm}$ long, $28 \mathrm{~cm}$ tall, $22 \mathrm{~cm}$ wide; mass $=4.8 \mathrm{~kg}$ ) has a depth rating of $170 \mathrm{~m}$, a 570-line color camera with wideangle $\left(116^{\circ}\right)$ lens, and is equipped with a red laser scaler to estimate fish size. The laser scaler consists of two $5 \mathrm{~mW}, 635 \mathrm{~nm}$ (red) class IIIa lasers mounted in a fixed position $75 \mathrm{~mm}$ apart, allowing for estimation of fish size using the ratio of the distance between lasers to the distance between snout and fork length of fishes observed onscreen (Patterson et al. 2009, Dance et al. 2011). The ROV was tethered to the surface and controlled by a pilot via an integrated control box that contains a $38 \mathrm{~cm}$ video monitor to observe and capture the digital video feed from the ROV's camera. Additionally, a GoPro Hero4 high definition (1080p at $120 \mathrm{fps}$ ) digital camera was mounted to the forward view of the ROV to provide high definition video for reef fish community surveys.

The ROV-based point-count sampling method described by Patterson et al. (2009) was employed to estimate reef fish community structure in a $15 \mathrm{~m}$ wide cylinder with reefs at the center of the cylinder's base. High definition video samples were viewed in a darkroom on a Sony LMD-2110W high-resolution LCD monitor to enumerate and identify reef fishes to the lowest taxonomic level possible. A second video reader independently analyzed randomly selected video samples $(n=16)$ to estimate reader agreement. Differences between reader estimates were evaluated by computing the average percent error (APE) for each taxon in a given sample, following Beamish \& McFarlane (1983). The mean of site-specific APEs across all taxa was computed to produce an overall APE between readers.

Total length (TL) was estimated for lionfish struck by the laser scaler if lionfish orientation was estimated to be less than $20^{\circ}$ from perpendicular to lasers in order to minimize measurement error (Patterson et al. 2009). Fish size was estimated by first multiplying the length of a fish measured in a video frame by the known distance between lasers $(75 \mathrm{~mm})$, and then dividing that product by the distance measured between lasers in the frame. Patterson et al. (2009) estimated a mean negative bias of $3 \%(\mathrm{SD}=0.6)$ from this method; thus, our estimated lionfish TL was biascorrected based on a random probability draw and normally distributed bias with a mean equal to $3 \%$ and a SD of $0.6 \%$. Total length distributions of lionfish on control sites were gathered from ROV estimates of TL. A 1-factor ANOVA was computed to test whether estimates of mean lionfish length estimated with the ROV laser scaler were different among removal treatments at the start of the study in the fall of 2013.

\section{Targeted removals of lionfish}

Divers removed lionfish from study reefs via spearfishing. Divers were able to capture and remove all lionfish present from reef structure and surrounding seabed during removal events. Initial removals on clear-once and maintain-clear sites were performed in January and February 2014, and then repeated on maintain-clear sites in July and August 2014, and in February and May 2015. Poor weather conditions prevented February and May 2015 removal events from occurring closer in time. Lionfish were speared immediately posterior to the skull-spinal column juncture and then placed in a saltwater ice slurry to euthanize. Each lionfish removed was weighed to the nearest $0.1 \mathrm{~g}$ and measured to nearest $\mathrm{mm}$ TL. The growth function reported by Barbour et al. (2011) for lionfish in USA waters was then solved for age and used to predict age distributions from the TL data obtained from culled fish. A linear regression was computed between lionfish counts from the ROV video samples and lionfish subsequently removed by divers at clear-once or maintain-clear reefs to test for bias in the ROV-derived lionfish counts.

\section{Data analysis}

Pre-removal experiment

Permutational analysis of variance (PERMANOVA) models were computed with the Primer statistical package (ver. 6; Anderson et al. 2008) to test for differences in reef fish community structure. Taxaspecific fish densities (fish $100 \mathrm{~m}^{-2}$ ) were the dependent variables in PERMANOVA models, which were computed with standardized (by total sample abundance) untransformed fish density data, using 
Bray-Curtis dissimilarities with 10000 permutations. Models tested whether the pattern in the similarity matrices between levels of factors was significantly different from random. Single-factor PERMANOVA models were computed to test for differences in reef fish community structure between samples collected in 2009-2010 versus 2011-2012 for all fishes, as well as separately for exploited species (e.g. snappers, groupers, porgies, triggerfish and jacks; Table S1 in the Supplement at www.int-res.com/articles/suppl/ m558p207_supp.pdf) and small demersal reef fishes (e.g. damselfishes, cardinalfishes, blennies, wrasses, gobies; Table S1 in the Supplement). In the model, reef surveys were nested within reefs across time to account for repeated sampling of individual reefs over time. This partitioning of variance accounted for differences within individual reefs and resulted in a residual error term inappropriate to test the effect of differences among individual reefs (Zar 1999, Hinkle et al. 2003), nor was this effect of primary interest to the study. Thus, F-ratios and p-values were not interpreted for effects of individual reefs in all repeated measures analyses.

Species-specific contrasts were performed for the 25 most abundant species with single-factor permutational ANOVA models computed in Primer (ver. 6; Anderson et al. 2008) to test for differences in fish density between 2009-2010 and 2011-2012 time periods. In the models, reef surveys were nested within reefs across time to account for repeated sampling of individual reefs over time. One-factor repeated measures ANOVAs also were computed to test the effect of time on reef fish diversity indices of species richness (number of species present), diversity (Shannon-Wiener $H^{\prime}$ ), and evenness (Pielou's $J^{\prime}$ ), as well as number of individuals (individuals from all species). For all ANOVA models, assumptions of normality and equal variances were assessed with Shapiro-Wilks (stats package) and Levene's (Fox \& Weisberg 2011, 'car' package) tests, respectively, within R (version 3.1.1; R Core Team 2015). Data met the assumption of equal variances in all models, but normality was occasionally violated. Given ANOVA is robust to minor departures from normality (Schmider et al. 2010), models were computed with untransformed data.

\section{Removal experiment}

A single-factor PERMANOVA model was computed to test for differences in reef fish community structure between treatments among 27 reefs at the beginning of the removal experiment. Two-factor PERMANOVA models were computed to test the effect of removal treatment, sample timing, and their interaction on reef fish community structure among all fishes, as well separately for exploited species (Table $\mathrm{S} 1$ in the Supplement) and small demersal reef fishes (Table S1). Reef sites were nested within treatment to account for repeated sampling of reefs over time. Given only one sample (reef survey) occurred at each site during each time period, the highest order interaction, 'site(treatment) $\times$ time', was excluded from the model (Anderson et al. 2008). For any significant main effect (at $\alpha=$ $0.05)$, post-hoc pairwise tests were computed with 10000 permutations.

Two-factor repeated measures ANOVAs were computed to test the effect of removal treatment, sample timing, and their interaction on reef fish diversity indices of species richness (number of species present), $H^{\prime}$ and $J^{\prime}$, as well as number of individuals (individuals from all species) and lionfish density. Pairwise multiple comparison procedures (Tukey's tests) were used to test which levels were different when a main effect was detected. Onefactor repeated measures ANOVAs also were computed to test whether reef fish diversity indices (species richness, $H^{\prime}$ and $J^{\prime}$ ) and the number of individuals (individuals from all species) were different among all time periods (2009-2010, 2011-2012, and 2013-2014). The 2013-2014 time period included data from all reefs prior to removals and only control sites following removals.

Video samples collected with ROV at clear-once reefs following lionfish removal in January and February 2014 enabled the estimation of lionfish recolonization rate over the remainder of the study. A linear mixed-effects regression was fit using restricted maximum likelihood to estimate the relationship between lionfish density and time since removal (Pinheiro et al. 2016, 'nlme' package). In the model, estimated lionfish density was the response variable, with days since removal as a fixed effect and reef site as a random effect to account for non-independence among repeat samples of the same reefs. The model formula in $\mathrm{R}$ is therefore: estimated lionfish density $\sim$ days since removal + (1 | reef), where ' 1 ' assumes different intercepts for each reef (i.e. multiple responses dependent on reef). $\mathrm{R}^{2}$ was calculated to describe the proportion of variance explained by both fixed and random factors (Nakagawa \& Schielzeth 2013). Confidence intervals $(95 \%)$ were calculated for model estimates of intercept and slope. 


\section{RESULTS}

We collected a total of 299 video samples at study reefs, with 221965 fish observed among 109 taxa (96.0\% identified to species). Of these samples, 137 were collected in 2009-2010 and 2011-2012 (83967 fish among 85 taxa), and 162 were collected during the removal experiment (137 998 fish among 80 taxa). Fish counts were compared between readers for 16 samples, which produced 191 taxa-specific paired comparisons. The overall APE between readers was $5.7 \%$ among these 16 video samples.
2009-2010 and 2011-2012 were beginning to stabilize relative to pre-invasion values by 2013-2014, but trends were not statistically significant for richness (Fig. 2, Table S2). General trends were declines in mean density, which were observed for 19 of the 25 most abundant reef fish species from 2009-2010 to 2011-2012 (Table 3). Out of these, statistically significant declines were observed in vermilion snapper Rhomboplites aurorubens ( $\mathrm{p}=0.026)$, twospot cardinalfish Apogon pseudomaculatus ( $\mathrm{p}=0.001)$, blue runner Caranx crysos $(\mathrm{p}=0.007)$, red porgy Pagrus pagrus $(\mathrm{p}=0.001)$, slippery dick Halichoeres bivitta-

\section{Pre-removal experiment}

No lionfish were observed in 2009-2010 video samples, but lionfish were observed when sampling resumed following the DWH event. Thus, lionfish first appeared on study reefs sometime between winter 2010 and fall 2011. There was a significant difference in reef fish community structure between 2009-2010 and 2011-2012 (PERMANOVA, $\mathrm{p}=0.015$ ) (Table 1 ). There also were differences in community structure of fishery species (PERMANOVA, $\mathrm{p}=0.042)$ (Table 1$)$ and small demersal species (PERMANOVA, p < 0.001) (Table 1) between 2009-2010 and 2011-2012, as well as in species richness and diversity (ANOVA, $\mathrm{p} \leq 0.002$; (Table 2, TableS2 in the Supplement). Higher diversity, as well as approximately $50 \%$ more species, were observed at study reefs in 2009-2010 than in 2011-2012; however, there was a general increase in number of individuals across all taxa in the latter time period (Fig. 2). The general increase in the mean number of individuals observed during 2011-2012 is mostly attributed to increases in small (<150 mm TL) pelagic planktivores (e.g. mackerel scad Decapterus macarellus) and tomtate Haemulon aurolineatum (Tables $2 \& 3$, Fig. S1 in the Supplement). Declines observed in species richness and diversity between
Table 1. PERMANOVA results of the model computed to test for differences in reef fish community structure (species composition and relative abundance) between samples collected in 2009-2010 versus 2011-2012 estimated from video samples collected with a remotely operated vehicle at study reefs. Significant $(\alpha<0.05) \mathrm{p}$-values are in bold

\begin{tabular}{|llccrrc|}
\hline Model & Source & df & Type III SS & MS & pseudo-F & p \\
\hline All fishes & Time & 1 & 21114 & 21114 & 3.46 & $\mathbf{0 . 0 1 5}$ \\
& Site (Time) & 34 & $2.13 \times 10^{5}$ & 6257 & & \\
& Residual & 101 & $1.86 \times 10^{5}$ & 1838 & & \\
& Total & 136 & $4.20 \times 10^{5}$ & & & \\
Exploited & Time & 1 & 14049 & 14049 & 2.42 & $\mathbf{0 . 0 4 2}$ \\
reef fishes & Site (Time) & 34 & $2.01 \times 10^{5}$ & 5927 & & \\
& Residual & 101 & $2.50 \times 10^{5}$ & 2479 & & \\
& Total & 136 & $4.67 \times 10^{5}$ & & & \\
Small demersal & Time & 1 & 27318 & 27318 & 4.37 & $<\mathbf{0 . 0 0 1}$ \\
reef fishes & Site (Time) & 34 & $2.17 \times 10^{5}$ & 6393 & & \\
& Residual & 101 & $2.63 \times 10^{5}$ & 2604 & & \\
& Total & 136 & $5.09 \times 10^{5}$ & & & \\
\hline
\end{tabular}

Table 2. One-way repeated measures ANOVA results for models computed to test the effect of timing, 2009-2010 versus 2011-2012, on reef fish diversity indices and number of individuals. Significant $(\alpha<0.05) \mathrm{p}$-values are in bold

\begin{tabular}{|llccccc|}
\hline Index & Source & df & Type III SS & MS & $F$ & p \\
\hline Species & Between subjects & 17 & 154.91 & 9.11 & & \\
richness & Between treatments & 1 & 130.34 & 130.34 & 65.10 & $<\mathbf{0 . 0 0 1}$ \\
& Residual & 17 & 30.04 & 2.00 & & \\
& Total & 35 & 319.29 & & & \\
Shannon- & Between subjects & 17 & 3.414 & 0.201 & & \\
Wiener & Between treatments & 1 & 0.766 & 0.766 & 13.462 & $\mathbf{0 . 0 0 2}$ \\
diversity, $H^{\prime}$ & Residual & 17 & 0.967 & 0.056 & & \\
& Total & 35 & 5.148 & & & \\
Pielou's & Between subjects & 17 & 0.339 & 0.020 & & \\
evenness, $J^{\prime}$ & Between treatments & 1 & 0.019 & 0.019 & 1.284 & 0.168 \\
& Residual & 17 & 0.158 & 0.009 & & \\
& Total & 35 & 0.517 & & & \\
No. of ind. & Between subjects & 17 & $3.29 \times 10^{6}$ & $1.94 \times 10^{5}$ & & \\
(across taxa) & Between treatments & 1 & $7.75 \times 10^{4}$ & $7.75 \times 10^{4}$ & \multirow{2}{*}{1.267} & 0.276 \\
& Residual & 17 & $1.04 \times 10^{6}$ & $6.12 \times 10^{4}$ & & \\
& Total & 35 & $4.41 \times 10^{6}$ & & & \\
\hline
\end{tabular}



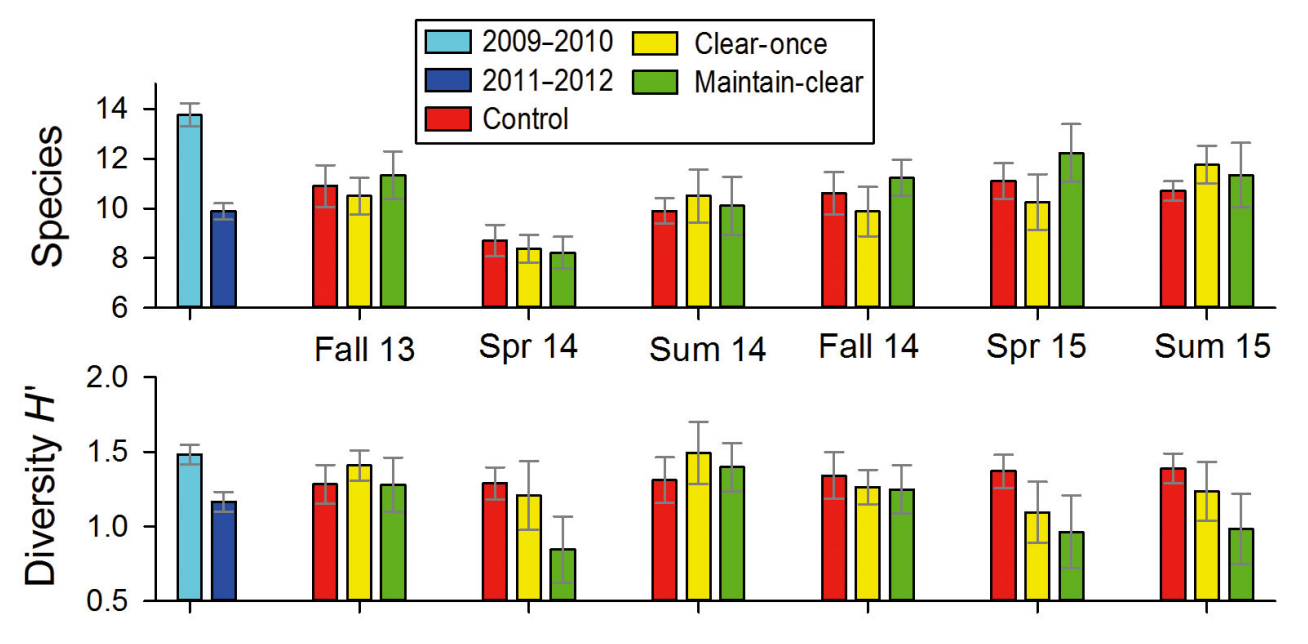

Fig. 2. Species diversity indices and number of individual fish across taxa on study reef sites during spring 2009-winter 2010, fall 2011summer 2012, and then computed during the lionfish removal experiment from fall 2013-summer 2015. Values are means $\pm \mathrm{SE}$. The diversity index $H^{\prime}$ is ShannonWiener diversity, and the evenness index $J^{\prime}$ is Pielou's evenness. Removals occurred between fall 2013 and spring 2014 (maintain-clear and clear-once), summer 2014 and fall 2014 (maintain-clear), and fall 2014 and spring 2015 (maintain-clear)

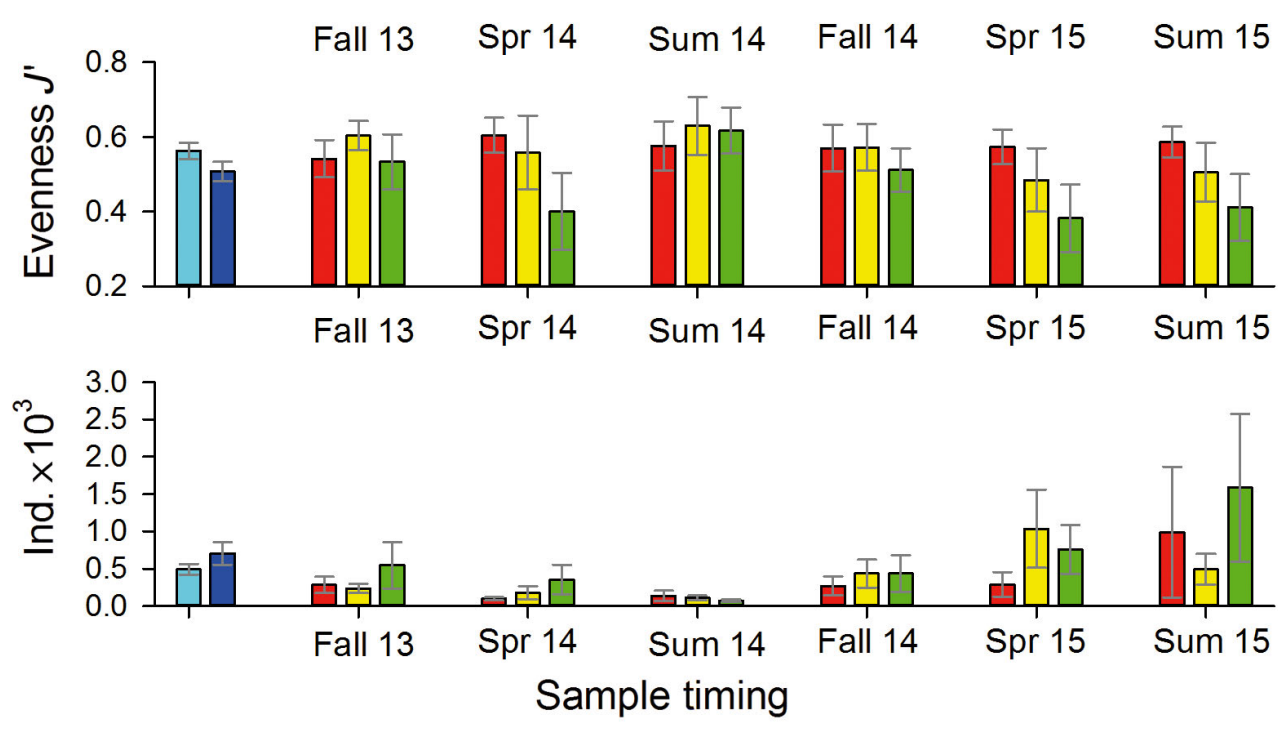

tus ( $\mathrm{p}=0.001)$, seaweed blenny Parablennius marmoreus $(p=0.001)$, yellowtail reeffish Chromis enchrysura $(\mathrm{p}=0.001)$, scaled sardine Harengula jaguana $(\mathrm{p}=0.018)$, gulf flounder Paralichthys albigutta $(\mathrm{p}=$ $0.006)$, and lesser amberjack Seriola fasciata $(p=0.001)$ (Table 3). While declines were observed for some larger predatory reef fishes (e.g. snappers, jacks, triggerfish) during 2011-2012, the biggest declines were seen in small $(<100 \mathrm{~mm})$ demersal planktivores and invertivores (Table S1, e.g. blennies, damselfishes, wrasses). The density of many of these small demersal species declined by $>90 \%$ between the 2009-2010 and 2011-2012 time periods (Table 3, Fig. S1).

\section{Removal experiment}

Six triannual ROV sampling events were conducted at study reefs from fall 2013 to summer 2015 for the lionfish removal experiment. A linear regres- sion relating numbers of lionfish removed and lionfish numbers counted in ROV samples was statistically significant $\left(F_{1,34}=283.4, \mathrm{p}<0.001, \mathrm{R}^{2}=0.90\right.$, lionfish removed $=1.47+1.29 \times$ lionfish count). The slope of 1.29 indicates that on average $29 \%$ more lionfish were removed from study reefs during removal events than had been estimated to exist on those reefs from ROV video samples. Therefore, ROV-based lionfish counts were scaled upward by a factor of 1.29 to account for incomplete detectability in ROV samples.

Unscaled lionfish counts in video samples ranged from 1 to 184 during the study, which translates to a density range of 0.7 to 103 fish $100 \mathrm{~m}^{-2}$. Estimated initial mean \pm SE lionfish density was not different among control, clear-once, and maintain-clear reefs and ranged from $28.9 \pm 12.3$ to $31.8 \pm 5.7$ fish (Fig. 3 \& Table 4). Divers removed 1575 individual lionfish from clear-once and maintain-clear study reefs, including 564 fish during the 2 follow-up removals at 
Table 3. Mean density (fish $100 \mathrm{~m}^{-2}$ ) and percent change in the 25 most abundant fishes observed at study artificial reef sites in 2009-2010 prior to lionfish presence versus in 2011-2012 after lionfish presence was confirmed. Significant ( $\alpha<0.05$ ) p-values in mean density between the time periods indicated with an asterisk ( $\left.{ }^{*}\right)$

\begin{tabular}{|c|c|c|c|c|c|c|}
\hline \multirow[t]{2}{*}{ Species } & \multirow[t]{2}{*}{ Common name } & \multicolumn{2}{|c|}{$2009-2010$} & \multicolumn{2}{|c|}{ 2011-2012 } & \multirow[t]{2}{*}{$\%$ Change } \\
\hline & & Mean density & $\mathrm{SE}$ & Mean density & $\mathrm{SE}$ & \\
\hline Decapterus macarellus & Mackerel scad & 82.1 & 33.8 & 236.9 & 69.7 & 188.7 \\
\hline Haemulon aurolineatum & Tomtate & 82.1 & 20.3 & 102.9 & 29.6 & 25.4 \\
\hline Lutjanus campechanus & Red snapper & 21.1 & 3.1 & 15.7 & 2.6 & -25.8 \\
\hline Rhomboplites aurorubens* & Vermilion snapper & 19.2 & 5.6 & 10.2 & 3.7 & -46.8 \\
\hline Apogon pseudomaculatus* & Twospot cardinalfish & 11.1 & 6.2 & 0.2 & 0.1 & -98.5 \\
\hline Caranx crysos $^{*}$ & Blue runner & 7.8 & 4.1 & 0.1 & 0.1 & -99.2 \\
\hline Centropristis ocyurus & Bank sea bass & 7.4 & 1.9 & 2.8 & 0.8 & -62.4 \\
\hline Pagrus pagrus* & Red porgy & 7.0 & 1.4 & 0.5 & 0.2 & -93.3 \\
\hline Halichoeres bivittatus* & Slippery dick & 6.9 & 1.9 & 0.5 & 0.2 & -92.6 \\
\hline Seriola dumerili & Greater amberjack & 5.0 & 0.9 & 6.8 & 2.1 & 36.3 \\
\hline Balistes capriscus & Gray triggerfish & 5.0 & 0.9 & 3.4 & 0.6 & -31.4 \\
\hline Parablennius marmoreus* & Seaweed blenny & 3.7 & 0.9 & 0.1 & - & -97.7 \\
\hline Lutjanus griseus & Gray snapper & 3.3 & 0.7 & 3.3 & 1.0 & 1.8 \\
\hline Lutjanus synagris & Lane snapper & 3.3 & 1.0 & 0.5 & 0.2 & -84.6 \\
\hline Rypticus maculatus & Whitespotted soapfish & 2.8 & 0.8 & 1.3 & 0.2 & -53.8 \\
\hline Chromis enchrysura* & Yellowtail reeffish & 2.0 & 0.4 & 0.0 & - & -99.6 \\
\hline Equetus lanceolatus & Jacknife fish & 1.7 & 0.5 & 1.2 & 0.3 & -30.0 \\
\hline Apogon sp. & Unidentified cardinalfishes & 0.8 & 0.6 & 0.0 & - & -100.0 \\
\hline Harengula jaguana* & Scaled sardine & 0.7 & 0.4 & 0.0 & - & -100.0 \\
\hline Canthigaster rostrata & Sharpnose puffer & 0.5 & 0.1 & 0.8 & 0.2 & 62.0 \\
\hline Paralichthys albigutta* & Gulf flounder & 0.5 & 0.2 & 0.0 & - & -100.0 \\
\hline Seriola fasciata* ${ }^{*}$ & Lesser amberjack & 0.4 & 0.1 & 0.0 & - & -100.0 \\
\hline Mycteroperca phenax* & Scamp & 0.4 & 0.1 & 0.8 & 0.1 & 88.8 \\
\hline Chaetodon ocellatus & Spotfin butterflyfish & 0.4 & 0.1 & 0.3 & 0.1 & -15.8 \\
\hline Epinephelus morio & Red grouper & 0.3 & 0.1 & 0.2 & - & -42.4 \\
\hline
\end{tabular}

maintain-clear reefs. There was a significant interaction between the effects of removal treatment and sample timing on lionfish density $\left(\mathrm{ANOVA}_{i} \mathrm{p}<\right.$ 0.001) (Table 4 \& Fig. 3). Densities of lionfish on control reefs significantly increased over the study period from $31.1 \pm 5.7$ fish $100 \mathrm{~m}^{-2}$ in fall 2013 to $49.2 \pm 7.9$ fish $100 \mathrm{~m}^{-2}$ in summer $2015(\mathrm{p}=0.042)$ (Table 4) despite a brief decline in abundance in December 2014 (Fig. 3). Across all sample periods, control reefs held higher densities of lionfish than maintain-clear $(p \leq 0.027)$ (Table 4$)$ reefs following the initial removal event. Control reefs held higher densities than clear-once sites for only 2 surveys immediately following lionfish removal ( $\mathrm{p} \leq 0.004)$ (Fig. 3 \& Table 4). On maintain-clear reefs, lionfish density was only significantly different between December 2013 and March 2014, the sampling periods immediately prior to and following removal $(\mathrm{p}=$ 0.003) (Fig. 3 \& Table 4), and May $2015(\mathrm{p}=0.020)$. Following their removal from clear-once and maintain-clear sites in January and February 2014, lionfish densities increased to $4.1 \pm 2.0$ fish $100 \mathrm{~m}^{-2}$ at maintain-clear and $5.2 \pm 1.6$ ) fish $100 \mathrm{~m}^{-2}$ at clearonce reefs by March 2014 (Fig. 3). Estimates of lion- fish density on maintain-clear sites averaged $9.7 \pm$ 1.5 fish $100 \mathrm{~m}^{-2}$ among all ROV sampling events that on average occurred 2.3 mo after lionfish removal events (Fig. 3). Lionfish density steadily increased in the year following the single removal event on clearonce reefs, and densities recovered to pre-removal levels by July 2014 ( $p=0.153$ ) (Fig. 3 \& Table 4$)$. The initial, pre-removal mean lionfish density on clearonce reefs was surpassed by the end of the study (Fig. 3).

There was no difference among treatments in the initial fall 2013 estimates of mean lionfish size estimated with the ROV laser scaler (ANOVA, $F_{2,18}=$ $2.77, \mathrm{p}=0.089$ ), which ranged from $207 \mathrm{~mm}$ on maintain-clear reefs to $242 \mathrm{~mm}$ on control reefs. Estimated TL of lionfish $(\mathrm{n}=222)$ on control reefs over the study period ranged from 134 to $456 \mathrm{~mm}$ (Fig. S2 in the Supplement), but the size distribution of fish mostly fell between 150 and $350 \mathrm{~mm}$ TL. Length frequency distributions from removal events at clear-once and maintain-clear treatments were computed from the 1575 culled individual lionfish. Among all sites, total lengths of removed lionfish ranged from 74 to $376 \mathrm{~mm}$ (Fig. S3 in the Supple- 


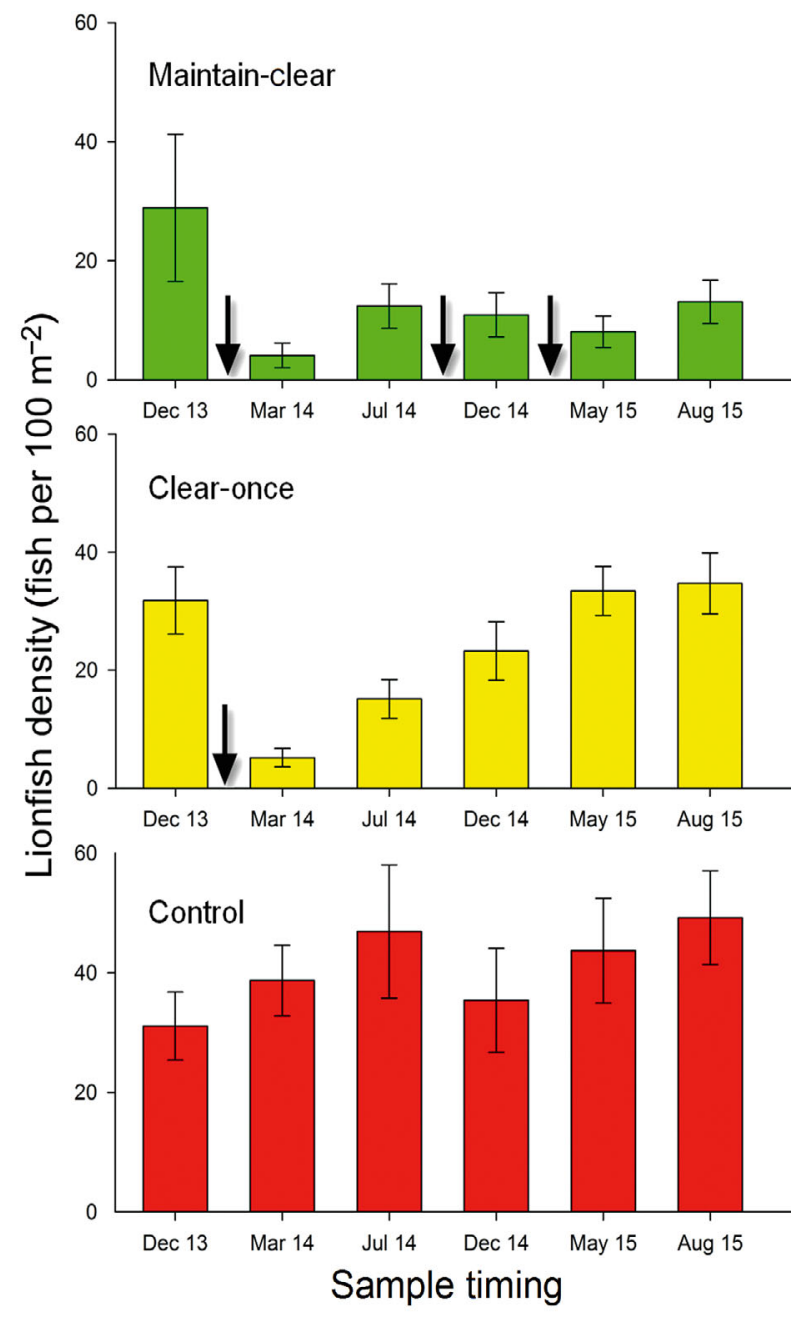

Fig. 3. Mean $( \pm \mathrm{SE})$ lionfish density estimated from counts made with a remotely operated vehicle (ROV) and then scaled $(\times 1.29)$ to correct for incomplete detectability. Arrows indicate timing of lionfish removal efforts between ROV samples

ment). Length distributions for clear-once and maintain-clear reefs from the initial removal event were similar and skewed toward larger-sized lionfish (>200 mm TL; Fig. S3A,B). Age distributions estimated with the growth function reported by Barbour et al. (2011) indicated the majority of lionfish from both treatments were 1 and 2 yr old fish (Fig. S3F,G). The size distribution of lionfish removed from maintain-clear reefs in July 2014 had 2 distinct modes, with the predominant mode centered on 150 $\mathrm{mm}$ TL (Fig. S3C). Therefore, fish that recruited to cleared reefs following the initial removal events in January and February 2014 likely consisted of a large percentage of age- 0 fish, as well as individuals as old as 4 yr (Fig. S3G). The final removal events conducted at maintain-clear reefs in February-May 2015 had fewer small (<200 mm TL) fish than the previous removal event, but more than were originally removed in early 2014 (Fig. S3E).

Reef fish communities were not different between treatments at the beginning of the experiment prior to removals. Removal treatment had significant effects on reef fish community structure. For the PERMANOVA model containing all reef fish taxa, both treatment $(p=0.021)$ and sample timing $(p=0.001)$ were significant, but their interaction was not $(\mathrm{p}=$ 0.254, Table 5). Reef fish communities on control reefs were significantly different from both removal

Table 4. Two-factor repeated measures ANOVA results for model computed to test the effects of lionfish removal treatment (Treat: control, clear-once, maintain-clear) and sample timing on lionfish density (fish $\times 100 \mathrm{~m}^{-2}$ ) estimates at study artificial reefs. Post hoc pairwise multiple comparisons (Tukey) for significant main test results follow. Significant $(\alpha<0.05) \mathrm{p}$-values are in bold

\begin{tabular}{|c|c|c|c|c|c|}
\hline Source & $\mathrm{df}$ & Type III SS & MS & $F$ & $\mathrm{p}$ \\
\hline Treat & 2 & 22586 & 11293 & 7.71 & 0.003 \\
\hline Site(Treat) & 24 & 35154 & 1465 & & \\
\hline Timing & 5 & 4727 & 945 & 5.05 & $<0.001$ \\
\hline Treat $\times$ Timing & 10 & 7034 & 703 & 3.75 & $<0.001$ \\
\hline Residual & 120 & 22484 & 187 & & \\
\hline \multirow[t]{2}{*}{ Total } & 161 & 91494 & & & \\
\hline & \multicolumn{4}{|c|}{ Sample timing } & 5 Aug 15 \\
\hline $\begin{array}{l}\text { Control vs. } \\
\text { maintain-clear }\end{array}$ & 0.970 & 0.0010 .00 & $01 \quad 0.027$ & $<0.001$ & $1<0.001$ \\
\hline $\begin{array}{l}\text { Control vs. } \\
\text { clear-once }\end{array}$ & 0.997 & 0.0020 .00 & $04 \quad 0.412$ & 0.528 & 0.285 \\
\hline $\begin{array}{l}\text { Clear-once vs. } \\
\text { maintain-clear }\end{array}$ & 0.953 & $0.994 \quad 0.95$ & $58 \quad 0.419$ & 0.031 & 0.076 \\
\hline Timing & Dec 13 & Mar $14 \mathrm{~J}$ & Jul $14 \quad \mathrm{I}$ & Dec 14 & May 15 \\
\hline \multicolumn{6}{|l|}{ Control } \\
\hline Mar 14 & 0.815 & & & & \\
\hline Jul 14 & 0.110 & 0.763 & & & \\
\hline Dec 14 & 0.982 & 0.994 & 0.420 & & \\
\hline May 15 & 0.316 & 0.964 & 0.995 & 0.752 & \\
\hline Aug 15 & 0.042 & 0.525 & 0.999 & 0.220 & 0.946 \\
\hline \multicolumn{6}{|l|}{ Clear-once } \\
\hline Mar 14 & 0.002 & & & & \\
\hline Jul 14 & 0.153 & 0.693 & & & \\
\hline Dec 14 & 0.811 & 0.096 & 0.843 & & \\
\hline May 15 & 1.000 & 0.001 & 0.089 & 0.673 & \\
\hline Aug 15 & 0.998 & $<0.001$ & 0.056 & 0.553 & 1.000 \\
\hline \multicolumn{6}{|l|}{ Maintain-clear } \\
\hline Mar 14 & 0.003 & & & & \\
\hline Jul 14 & 0.116 & 0.793 & & & \\
\hline Dec 14 & 0.067 & 0.898 & 1.000 & & \\
\hline May 15 & 0.020 & 0.989 & 0.986 & 0.998 & \\
\hline Aug 15 & 0.149 & 0.729 & 1.000 & 0.999 & 0.971 \\
\hline
\end{tabular}


Table 5. PERMANOVA results for models computed to test the effects of lionfish removal treatment (Treat: control, clear-once, maintain-clear) and sample timing on reef fish community structure (species composition and relative abundance) estimated from video samples collected with a remotely operated vehicle at study reefs. Significant $(\alpha<0.05) p$-values are in bold

\begin{tabular}{|llccccc|}
\hline Model & Source & df & Type III SS & MS & pseudo-F & p \\
\hline All fishes & Treat & 2 & 51242 & 25621 & 2.70 & $\mathbf{0 . 0 2 1}$ \\
& Timing & 5 & 16587 & 3317 & 2.24 & $\mathbf{0 . 0 0 1}$ \\
& Site(Treat) & 24 & $2.27 \times 10^{5}$ & 9474 & & \\
& Treat $\times$ Timing & 10 & 16770 & 1677 & 1.13 & 0.254 \\
& Residual & 120 & $1.77 \times 10^{5}$ & 1482 & & \\
& Total & 161 & $4.90 \times 10^{5}$ & & & \\
Exploited & Treat & 2 & 10677 & 5338 & 0.71 & 0.641 \\
reef fishes & Timing & 5 & 27020 & 5404 & 4.42 & $\mathbf{0 . 0 0 1}$ \\
& Site(Treat) & 24 & $1.83 \times 10^{5}$ & 7621 & & \\
& Treat $\times$ Timing & 10 & 13149 & 1315 & 1.07 & 0.356 \\
& Residual & 116 & $1.42 \times 10^{5}$ & 1224 & & \\
Small & Total & 157 & $3.76 \times 10^{5}$ & & & \\
demersal & Treat & 2 & 19348 & 9674 & 0.88 & 0.489 \\
reef fishes & Timing & 5 & 20130 & 4026 & 3.37 & $\mathbf{0 . 0 0 1}$ \\
& Site(Treat) & 24 & $2.62 \times 10^{5}$ & 10948 & & \\
& Treat $\times$ Timing & 10 & 9874 & 987 & 0.83 & 0.805 \\
& Residual & 119 & $1.42 \times 10^{5}$ & 1195 & & \\
& Total & 160 & $4.54 \times 10^{5}$ & & & \\
\hline
\end{tabular}

Table 6. Two-way repeated measures ANOVA results for models computed to test the effects of lionfish removal treatment (Treat: control, clear-once, maintain-clear) and sample timing on reef fish diversity indices and number of individuals. Significant $(\alpha<0.05)$ p-values are in bold

\begin{tabular}{|c|c|c|c|c|c|c|}
\hline Index & Source & df & Type III SS & MS & $F$ & $\mathrm{p}$ \\
\hline $\begin{array}{l}\text { Species } \\
\text { richness }\end{array}$ & $\begin{array}{l}\text { Treat } \\
\text { Site(Treat) } \\
\text { Timing } \\
\text { Treat } \times \text { Timing } \\
\text { Residual } \\
\text { Total }\end{array}$ & $\begin{array}{c}2 \\
24 \\
5 \\
10 \\
120 \\
161\end{array}$ & $\begin{array}{c}8.34 \\
468.44 \\
149.33 \\
26.83 \\
494.17 \\
1147.61\end{array}$ & $\begin{array}{c}4.17 \\
19.52 \\
29.87 \\
2.68 \\
4.12\end{array}$ & $\begin{array}{l}7.252 \\
0.652\end{array}$ & $\begin{array}{r}<\mathbf{0 . 0 0 1} \\
0.767\end{array}$ \\
\hline $\begin{array}{l}\text { Shannon- } \\
\text { Wiener } \\
\text { diversity } H^{\prime}\end{array}$ & $\begin{array}{l}\text { Treat } \\
\text { Site(Treat) } \\
\text { Timing } \\
\text { Treat } \times \text { Timing } \\
\text { Residual } \\
\text { Total }\end{array}$ & $\begin{array}{c}2 \\
24 \\
5 \\
10 \\
120 \\
161\end{array}$ & $\begin{array}{c}1.35 \\
18.50 \\
1.64 \\
1.56 \\
19.50 \\
42.41\end{array}$ & $\begin{array}{l}0.68 \\
0.77 \\
0.33 \\
0.16 \\
0.16\end{array}$ & $\begin{array}{l}2.015 \\
0.962\end{array}$ & $\begin{array}{l}0.081 \\
0.481\end{array}$ \\
\hline $\begin{array}{l}\text { Pielou's } \\
\text { Evenness } J^{\prime}\end{array}$ & $\begin{array}{l}\text { Treat } \\
\text { Site(Treat) } \\
\text { Timing } \\
\text { Treat } \times \text { Timing } \\
\text { Residual } \\
\text { Total }\end{array}$ & $\begin{array}{c}2 \\
24 \\
5 \\
10 \\
120 \\
161\end{array}$ & $\begin{array}{l}0.31 \\
2.77 \\
0.28 \\
0.28 \\
3.52 \\
7.13\end{array}$ & $\begin{array}{l}0.16 \\
0.12 \\
0.06 \\
0.03 \\
0.03\end{array}$ & $\begin{array}{l}1.911 \\
0.951\end{array}$ & $\begin{array}{l}0.097 \\
0.490\end{array}$ \\
\hline $\begin{array}{l}\text { No. of ind. } \\
\text { (across taxa) }\end{array}$ & $\begin{array}{l}\text { Treat } \\
\text { Site(Treat) } \\
\text { Timing } \\
\text { Treat Timing } \\
\text { Residual } \\
\text { Total }\end{array}$ & $\begin{array}{c}2 \\
2 \\
5 \\
10 \\
120 \\
161\end{array}$ & $\begin{array}{l}2.38 \times 10^{6} \\
7.15 \times 10^{7} \\
1.54 \times 10^{7} \\
6.29 \times 10^{6} \\
1.15 \times 10^{8} \\
2.11 \times 10^{8}\end{array}$ & $\begin{array}{l}1.19 \times 10^{6} \\
2.98 \times 10^{6} \\
3.09 \times 10^{6} \\
6.29 \times 10^{5} \\
1.30 \times 10^{6}\end{array}$ & $\begin{array}{l}3.216 \\
0.655\end{array}$ & $\begin{array}{l}\mathbf{0 . 0 0 9} \\
0.764\end{array}$ \\
\hline
\end{tabular}

treatments (PERMANOVA, $\mathrm{p} \leq 0.034$ ), but removal treatments were not significantly different from each other (PERMANOVA, $\mathrm{p}=0.333$ ) (Table S3 in the Supplement). Models computed for exploited species and small demersal fishes produced different results wherein the effect of sample timing was significant, but treatment and the interaction between the main effects were not (Table 5). Substantial gains in abundance were not observed for most taxa regardless of lionfish removal effort (Fig. S1 in the Supplement). Modest increases in mean density were seen for bank sea bass Centropristis ocyurus, pelagic planktivores (e.g. scads, sardines), small demersal fishes (e.g. damselfishes, cardinalfishes) and slippery dick Halichoeres bivittatus from targeted lionfish removals (Fig. S1). Removal treatment did not affect any of the reef fish diversity indices measured (Table 6, Fig. 2). The effect of sample timing was significant for species richness, but not for diversity or evenness (Table 6, Table S4 in the Supplement, Fig. 2). Differences in numbers of individuals across taxa stemmed from low numbers in spring and summer 2014 compared to increases in numbers in summer 2015 (Fig. 2, Table S4). There were no significant interactions between removal treatment and sample timing on any reef fish diversity index (Table 6).

The linear mixed model regression fit to lionfish density versus experiment day for clear-once reefs was significant with a slope $( \pm 95 \%$ CI $)$ of $0.063 \pm 0.011$ lionfish $100 \mathrm{~m}^{-2} \mathrm{~d}^{-1}$ (Fig. 4). Therefore, the density of lionfish on cleared reefs was estimated to increase by 1 fish $100 \mathrm{~m}^{-2}$ approximately every $16 \mathrm{~d}$.

\section{DISCUSSION}

Extensive baseline data on reef fish community structure at both natural and artificial reefs in the nGOM (e.g. 


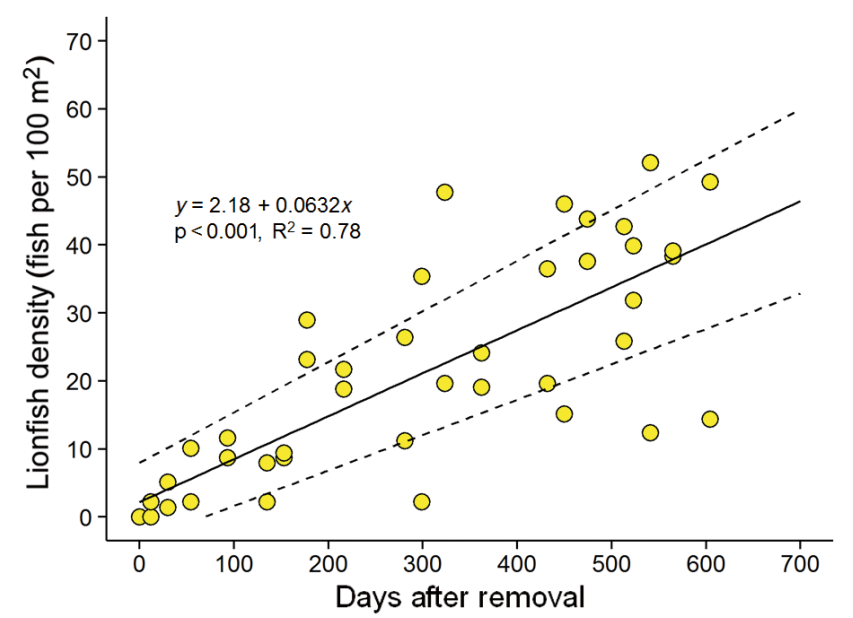

Fig. 4. Scatterplot of estimated lionfish density (scaled upward by a factor of 1.29 for incomplete detectability) versus days after lionfish removal for clear-once experimental artificial reef sites and the line fit to the significant fixed effect of days after removal. The intercept $( \pm 95 \% \mathrm{CI})$ is the average of coefficients from individual reefs in the model. The slope $( \pm 95 \% \mathrm{CI})$ is the recolonization rate of lionfish to all cleared reefs, taking individual reef variation into account

Dance et al. 2011, Patterson et al. 2014) have enabled us to track the lionfish invasion in this region (Dahl \& Patterson 2014). Results presented here for artificial reef study sites off northwest Florida clearly demonstrate that shifts in reef fish community structure occurred between 2009-2010 and 2011-2012, time periods which bracket the appearance of lionfish in the nGOM region (Dahl \& Patterson 2014). Taxa-specific differences were most pronounced for small demersal reef fishes, such as damselfishes, cardinalfishes, wrasses, and blennies, which have been documented as predominant prey of lionfish (Albins \& Hixon 2008, Morris \& Akins 2009, Dahl \& Patterson 2014). In fact, local depletion or extirpation of these taxa due to lionfish predation has been reported in other systems (Green et al. 2012, Albins 2015). Lionfish densities on nGOM artificial reefs were among the highest in the western Atlantic by fall 2013 (Dahl \& Patterson 2014), and mean density had already reached nearly 10 fish $100 \mathrm{~m}^{-2}$ on our study reefs by fall 2012. This is significant in that such densities are above threshold values where ecological impacts have been predicted to occur on Caribbean reefs (Green et al. 2014, Benkwitt 2015).

Observed shifts in reef fish community structure following the arrival of lionfish in the nGOM seem like compelling evidence of lionfish effects, especially given similar declines attributed to lionfish in other parts of their invaded range. However, the occurrence of the DWH in summer 2010 is a con- founding factor in drawing inference about potential ecological impacts of lionfish in this region. Estimates of the spatial extent of DWH surface oil extended over our study area periodically from April to August 2010 (Goni et al. 2015). There is clear evidence that some nGOM reef fishes were exposed to toxic petroleum compounds released during the spill (Murawski et al. 2014), with documented impacts on fishes including genetic effects, shifts in trophic position, declines in size at age, and changes in community structure (Whitehead et al. 2012, Norberg 2015, NOAA-NRDA 2015, Tarnecki \& Patterson 2015). Therefore, it is possible that reef fish declines observed at study reefs in 2011-2012 were initially driven by the DWH. Declines observed in larger species, such as snappers and gray triggerfish, during 2011-2012 versus 2009-2010 could have resulted from mortality due to the spill or emigration from spill-affected areas. Few of these species settle directly on reefs, but instead recruit to reefs following months to years in intermediate nursery habitats, such as Sargassum wracks, seagrass beds, or shell rubble reefs. Therefore, it is unlikely that lionfish directly consumed these groups on our study reefs, a conclusion supported by diet data (Dahl \& Patterson 2014). Small demersal fishes, such as damselfishes, cardinalfishes, wrasses, blennies, and gobies, are obligate reef residents, settle directly from the plankton onto reef habitat, and are much more siteattached than the larger taxa described above. Therefore, localized effects of lionfish were more likely to have affected small demersal fishes directly as opposed to larger and more mobile species.

Our inability to definitely state that reef fish community shifts predated lionfish becoming wellestablished on study reefs partly stems from the fact that no data on fish community structure were collected at the study reefs during the year immediately following the DWH when mean lionfish density ( $\sim 5$ fish $100 \mathrm{~m}^{-2}$ ) was less than predicted threshold values from the Caribbean (Dahl \& Patterson 2014, Green et al. 2014). However, declines in the number of species and lower species diversity observed in 2011-2012 relative to 2009-2010 showed signs of stabilizing by 2013, with the possibility of a reversing trend. This occurred while mean lionfish density on study reefs increased to over 30 fish $100 \mathrm{~m}^{-2}$, and mean mass of individuals had nearly doubled over what was observed in fall 2011 (Dahl \& Patterson 2014). Therefore, despite an increasing lionfish population in the region, and specifically on our study reefs, fish communities had somewhat stabilized from declines observed following 2009-2010. One 
group that did not experience density or diversity increases during 2013, however, was small demersal fishes. Given these taxa are the predominant prey of lionfish in this and other systems, exponentially increasing lionfish populations after 2012 may have then suppressed any resiliency these groups may have otherwise shown in recovery from the DWH event or limited lionfish presence.

Regardless of the ultimate cause(s) of reef fish community structure shifts observed between 2009-2010 and 2011-2012, a central goal of this study was to conduct lionfish removal events to examine what level of effort would be required to facilitate recovery in affected communities. Targeted removals from nGOM artificial reefs did significantly reduce lionfish density. However, reductions were short-lived as juvenile and adult lionfish rapidly recruited to cleared reefs. Lionfish were observed on cleared reefs as early as a week after removing all lionfish, and more than 500 individuals were removed from maintain-clear reefs during follow-up removal events during the year following initial culling. One year after lionfish removal, clear-once sites had lionfish densities comparable to those of control reefs, and mean lionfish density on clear-once reefs eventually surpassed the levels initially observed in fall 2013. When accounting for incomplete detectability, our estimates of lionfish density illustrate the extent to which the nGOM region is invaded. Mean densities from our control sites throughout the study, and clear-once sites at the conclusion of the study, were 8- to 10-fold higher than the mean density (4.4 fish $100 \mathrm{~m}^{-2}$ ) reported by Hackerott et al. (2013) in a meta-analysis of lionfish densities on Caribbean reefs. This may explain why we failed to see lasting lionfish reductions in both population numbers and size. Indeed, results reported here are consistent with models that predict sustained removal efforts are required to control lionfish populations (AriasGonzález et al. 2011, Barbour et al. 2011, Morris et al. 2011a), perhaps at intensities greater than has been performed elsewhere in the invaded range (Frazer et al. 2012, de León et al. 2013, Benkwitt 2015).

A reduction in the mean size of lionfish present in the system would be a desirable management outcome as it could reduce cumulative predation on vulnerable reef fishes given that lionfish diet shifts with ontogeny and proportionally more fish are consumed at larger sizes (Morris \& Akins 2009, Dahl \& Patterson 2014). Larger, mature individuals also have higher energetic demands and consume prey at higher rates than smaller sized fish (Cerino et al. 2013). Recruitment and settlement of juvenile lionfish onto previ- ously cleared reefs was high following the first removal event in early 2014, effectively lowering the mean size of individuals at both maintain-clear and clear-once reefs. However, the size distribution of lionfish present at maintain-clear reefs from the final removals in February and May 2015 had shifted back toward larger adults, thus mostly negating early reductions in mean size of lionfish.

The early life history and recruitment dynamics of invasive lionfish are not well understood. Therefore, little information exists to evaluate whether juveniles that recruited to cleared reefs were more likely to have local or distant sources. Adult lionfish also quickly recruited to cleared reefs, which means they had to swim long $(>300 \mathrm{~m}$ ) distances over open substrate to study reefs that were isolated from any natural reef habitat ( $>5 \mathrm{~km}$ ) and located between $300 \mathrm{~m}$ and $1 \mathrm{~km}$ from adjacent artificial reefs. This inference contrasts with reports of limited adult or post-settlement movement in estuarine (Jud \& Layman 2012), southeast Atlantic natural hardbottom (Bacheler et al. 2015), and Caribbean patch and continuous coral reef ecosystems (Akins et al. 2014), where site fidelity of lionfish has been reported to be high, and may explain the higher degree of success of targeted removal efforts in such areas (Frazer et al. 2012). Our findings support recent work that indicates that lionfish display lower site fidelity under high-density conditions (Tamburello \& Côté 2015). Lionfish densities observed on control reefs throughout our study represent the highest values reported across their invaded range; thus, intraspecific competition for prey resources may be prompting movement on greater scales than has been reported previously (Tamburello \& Côté 2015). Consistent with that hypothesis is the fact that non-reef benthic fishes (e.g. lizardfishes, flounders, sea robins) and invertebrates constituted significantly greater proportions of lionfish diet at nGOM artificial reefs versus lionfish recovered from natural reefs (Dahl \& Patterson 2014). Therefore, lionfish associated with artificial reefs are clearly spending time away from reefs foraging on non-reef associated prey. The extent of these movements and the area over which lionfish are utilizing prey resources is currently unknown, but conventional or acoustic tagging approaches could be employed to examine those questions.

The rapid recolonization rate of juvenile lionfish settling from the plankton and/or adults immigrating from nearby habitat onto cleared reefs resulted in lionfish densities that were rarely below thresholds proposed by others to mitigate ecological impacts to native fishes despite substantial removal 
effort (Green et al. 2014, Benkwitt 2015). This may be why our lionfish removals did not translate into significant gains for most fish taxa, though previous studies were mostly focused on small fishes likely to be consumed by lionfish. For larger species included in our analyses, the effects of lionfish were not apparent but may have been undetectable on the timescale studied, especially if impacts are indirect, competitive trophic interactions resulting in reduced growth or reproduction (Albins 2015). Additionally, this study differs from other removal experiments in that small demersal reef fishes (e.g. damselfishes, cardinalfishes, wrasses, blennies), which constitute high proportions of lionfish diet in systems or habitats where they are abundant, were already nearly absent from study reefs at the start of the experiment. While these species did increase somewhat following lionfish removals in this study, their densities remained less than $25 \%$ of the values observed in 2009-2010, or those reported by Dance et al. (2011) for even earlier time periods. Benkwitt (2015) reported that even single lionfish were able to negate substantial gains in lionfish prey species on small $\left(1 \mathrm{~m}^{3}\right)$ patch reefs in The Bahamas, and Green et al. (2014) reported that approximately $90 \%$ lionfish removal was required to foster ecological resiliency for native prey fish communities on larger $\left(100-150 \mathrm{~m}^{2}\right)$ Bahamian patch reefs. No such estimate yet exists for the nGOM region of a threshold lionfish density necessary to mitigate lionfish effects and foster ecosystem resiliency, but recolonization rates of lionfish following experimental removals at study reefs could be used hereafter to predict the level of harvesting effort that would be required to keep lionfish densities suppressed below some threshold. Indeed, our results predict that to maintain lionfish densities $<5$ fish $100 \mathrm{~m}^{-2}$, all lionfish must be harvested from reefs approximately every $2 \mathrm{mo}$, about twice the frequency performed in this study.

The extraordinary and continued success of invasive lionfish in the nGOM may be attributable to mechanisms of decreased biotic resistance or resilience. Disturbed ecosystems, regardless of causation, have been shown to be more vulnerable to invasion (Stachowicz et al. 2002). Indeed, recent trophic dynamic ecosystem simulations computed with an Ecopath with Ecosim model of the west Florida Shelf ecosystem indicate that depleted biomass of top predators (e.g. groupers, snappers) can influence the relative invasion success of lionfish (Chagaris et al. 2015). Evidence of native western Atlantic species preying on lionfish is rare; thus, top predators in the
Chagaris et al. (2015) model were assumed not to prey upon lionfish. The model also assumed no lionfish cannibalism; thus, no direct lionfish control was present in the model. Despite this, their results suggest that lionfish invasion success can be influenced through competitive trophic interactions. Historic overexploitation (i.e. overfishing) of top predators in the nGOM region, coupled with declines following the DWH, may have compromised ecosystem resistance to the initial invasion success of lionfish and contributed thereafter to their exponential increases in abundance and biomass.

Localized lionfish removal efforts in this study did not result in substantial gains in native reef fish abundance, but sustained removal efforts were somewhat effective at limiting lionfish densities to relatively low levels on nGOM artificial reefs. Unfortunately, regionally high lionfish densities may require more frequent removal efforts than we attempted, or on much larger spatial scales, to effect meaningful reductions in lionfish density and biomass. If expansive lionfish culling efforts could be accomplished on the shallow $(<40 \mathrm{~m}$ depth) shelf, lionfish populations associated with mesophotic reefs on the outer shelf and upper continental slope (i.e. below traditional recreational diving limits, $40 \mathrm{~m}$ ), or other areas that receive little to no control efforts, might still serve as constant sources of new lionfish recruits. Efforts to reduce lionfish biomass at those depths will be logistically challenging and expensive. Therefore, to see beneficial effects on local reef fish communities, lionfish removals going forward will require an effort high enough to offset recolonization from difficult to reach source populations. Ongoing ecosystem modeling efforts that are aimed at evaluating the ecological impacts of lionfish in the nGOM should be coupled with economic models to estimate the expense and feasibility of lionfish removal or harvesting efforts that will be required to accomplish the goal of minimizing lionfish impacts in the northern Gulf of Mexico.

Acknowledgements. We thank Joe Tarnecki for help with ROV sampling and video analysis, and Steve Garner, Justin Lewis, and Brian Klimek for help in the field and laboratory. We thank Johnny Greene, Gary Jarvis, Sean Kelley, Seth Wilson, and their crews for aid in ROV sampling. We thank Dalton Kennedy, Clint Retherford, and Scott Bartel for help in spearing lionfish. This research was made possible in part by a grant from BP/The Gulf of Mexico Research Initiative/C-IMAGE II, and in part by funding from the Florida Fish and Wildlife Conservation Commission. Data are available through the Gulf of Mexico Research Initiative Information \& Data Cooperative (GRIIDC) at https://data.gulfresearchinitiative.org. 


\section{LITERATURE CITED}

Aguilar-Perera A, Tuz-Sulub A (2010) Non-native, invasive red lionfish (Pterois volitans [Linnaeus, 1758]: Scorpaenidae), is first recorded in the southern Gulf of Mexico, off the northern Yucatan Peninsula, Mexico. Aquat Invasions 5:S9-S12

Akins JL, Morris JA, Green SJ (2014) In situ tagging technique for fishes provides insight into growth and movement of invasive lionfish. Ecol Evol 4:3768-77

Albins MA (2013) Effects of invasive Pacific red lionfish Pterois volitans versus a native predator on Bahamian coral-reef fish communities. Biol Invasions 15:29-43

Albins MA (2015) Invasive Pacific lionfish Pterois volitans reduce abundance and species richness of native Bahamian coral-reef fishes. Mar Ecol Prog Ser 522:231-243

Albins MA, Hixon MA (2008) Invasive Indo-Pacific lionfish Pterois volitans reduce recruitment of Atlantic coral-reef fishes. Mar Ecol Prog Ser 367:233-238

Albins MA, Hixon MA (2013) Worst case scenario: potential long-term effects of invasive predatory lionfish (Pterois volitans) on Atlantic and Caribbean coral-reef communities. Environ Biol Fishes 96:1151-1157

Anderson MJ, Gorley RN, Clarke KR (2008) PERMANOVA+ for PRIMER: guide to software and statistical methods. PRIMER-E, Plymouth

> Arias-González JE, González-Gándara C, Cabrera JL, Christensen V (2011) Predicted impact of the invasive lionfish Pterois volitans on the food web of a Caribbean coral reef. Environ Res 111:917-925

> Bacheler NM, Whitfield PE, Muñoz RC, Harrison BB, Harms CA, Buckel CA (2015) Movement of invasive adult lionfish Pterois volitans using telemetry: importance of controls to estimate and explain variable detection probabilities. Mar Ecol Prog Ser 527:205-220

> Barbour AB, Allen MS, Frazer TK, Sherman KD (2011) Evaluating the potential efficacy of invasive lionfish (Pterois volitans) removals. PLOS ONE 6:e19666

Beamish RJ, McFarlane GA (1983) The forgotten requirement for age validation in fisheries biology. Trans Am Fish Soc 112:735-743

Benkwitt CE (2015) Non-linear effects of invasive lionfish density on native coral-reef fish communities. Biol Invasions 17:1383-1395

Cerino D, Overton AS, Rice JA, Morris JA Jr (2013) Bioenergetics and trophic impacts of the invasive Indo-Pacific lionfish. Trans Am Fish Soc 142:1522-1534

Chagaris D, Binion S, Bodanoff A, Dahl K and others (2015) Modeling lionfish management strategies on the West Florida shelf: workshop summary and results. University of Florida, Gainesville, FL

Côté IM, Green SJ, Hixon MA (2013) Predatory fish invaders: insights from Indo-Pacific lionfish in the western Atlantic and Caribbean. Biol Conserv 164:50-61

Curtis-Quick J, Underwood E, Green S, Akins L, Harborne A, Côté I (2014) Interactions between the Caribbean spiny lobster, Panulirus argus, and invasive lionfish, Pterois volitans: Who displaces whom? Proc Gulf Caribb Fish Inst 66:199-200

> Dahl KA, Patterson WF III (2014) Habitat-specific density and diet of rapidly expanding invasive red lionfish, Pterois volitans, populations in the northern Gulf of Mexico. PLOS ONE 9:e105852

> Dance MA, Patterson WF III, Addis DT (2011) Fish community and trophic structure of reef fishes in the northeast- ern Gulf of Mexico. Bull Mar Sci 87:301-324

> de León R, Vane K, Bertuol P, Chamberland VC, Simal F, Imms E, Vermeij MJ (2013) Effectiveness of lionfish removal efforts in the southern Caribbean. Endang Species Res 22:175-182

DeLaune RD, Wright AL (2011) Projected impact of Deepwater Horizon oil spill on US Gulf Coast wetlands. Soil Sci Soc Am J 75:1602-1612

Ferguson T, Akins L (2010) The lionfish cookbook: the Caribbean's new delicacy. REEF Environmental Education Foundation, Key Largo, FL

Fogg AQ, Hoffmayer ER, Driggers WB III, Campbell MD, Pellegrin GJ, Stein W (2013) Distribution and length frequency of invasive lionfish (Pterois sp.) in the northern Gulf of Mexico. Gulf Caribb Res 25:111-115

Fox J, Weisberg S (2011) An R companion to applied regression, $2^{\text {nd }}$ edn. Sage, Thousand Oaks, CA

> Frazer TK, Jacoby CA, Edwards MA, Barry SC, Manfrino CM (2012) Coping with the lionfish invasion: Can targeted removals yield beneficial effects? Rev Fish Sci 20: 185-191

Goni GJ, Trinanes JA, MacFadyen A, Streett D and others (2015) Variability of the Deepwater Horizon surface oil spill extent and its relationship to varying ocean currents and extreme weather conditions. In: Ehrhardt M (ed) Mathematical modelling and numerical simulation of oil pollution problems. Springer International, Cham, p 1-22

Graham WM, Condon RH, Carmichael RH, D'Ambra I, Patterson HK, Linn LJ, Hernandez FJ Jr (2010) Oil carbon entered the coastal planktonic food web during the Deepwater Horizon oil spill. Environ Res Lett 5:045301

> Green SJ, Akins JL, Maljkovi A, Côté IM (2012) Invasive lionfish drive Atlantic coral reef fish declines. PLOS ONE $7: \mathrm{e} 32596$

Green SJ, Dulvy NK, Brooks AM, Akins JL, Cooper AB, Miller S, Côté IM (2014) Linking removal targets to the ecological effects of invaders: a predictive model and field test. Ecol Appl 24:1311-1322

Hackerott S, Valdivia A, Green SJ, Côté IM and others (2013) Native predators do not influence invasion success of Pacific lionfish on Caribbean reefs. PLOS ONE 8:e68259

Hinkle DE, Wiersma W, Jurs SG (2003) Applied statistics for the behavioral sciences, 5th edn. Houghton Mifflin, Boston, MA

Ingeman KE, Webster MS (2015) Native prey mortality increases but remains density-dependent following lionfish invasion. Mar Ecol Prog Ser 531:241-252

Jud ZR, Layman CA (2012) Site fidelity and movement patterns of invasive lionfish, Pterois spp., in a Florida estuary. J Exp Mar Biol Ecol 414-415:69-74

Layman CA, Allgeier JE (2012) Characterizing trophic ecology of generalist consumers: a case study of the invasive lionfish in The Bahamas. Mar Ecol Prog Ser 448:131-141

> Lesser MP, Slattery M (2011) Phase shift to algal dominated communities at mesophotic depths associated with lionfish (Pterois volitans) invasion on a Bahamian coral reef. Biol Invasions 13:1855-1868

Morris JA Jr, Akins JL (2009) Feeding ecology of invasive lionfish (Pterois volitans) in the Bahamian archipelago. Environ Biol Fishes 86:389-398

Morris JA Jr, Whitfield PE (2009) Biology, ecology, control and management of the invasive Indo-Pacific lionfish: an updated integrated assessment. NOAA Tech Memo NOS NCCOS 99:1-57 
Morris JA Jr, Shertzer K, Rice J (2011a) A stage-based matrix population model of invasive lionfish with implications of control. Biol Invasions 13:7-12

Morris JA Jr, Thomas A, Rhyne AL, Breen N, Akins L, Nash B (2011b) Nutritional properties of the invasive lionfish: a delicious and nutritious approach for controlling the invasion. AACL Bioflux 4:21-26

Muñoz RC, Currin CA, Whitfield PE (2011) Diet of invasive lionfish on hard bottom reefs of the Southeast USA: insights from stomach contents and stable isotopes. Mar Ecol Prog Ser 432:181-193

Murawski SA, Hogarth WT, Peebles EB, Barbeiri L (2014) Prevalence of fish diseases in the Gulf of Mexico post Deepwater Horizon. Trans Am Fish Soc 143:1084-1097

- Nakagawa S, Schielzeth H (2013) A general and simple method for obtaining $\mathrm{R}^{2}$ from generalized linear mixed effects models. Methods Ecol Evol 4:133-142

NOAA-NRDA (2015) Chapter 4. Injury to natural resources. In: Final Programmatic Damage Assessment and Restoration Plan and Final Programmatic Environmental Impact Statement. US Dept of Commerce, Silver Spring, MD, p 187-197

Norberg MA (2015) The ecology of tomtate, Haemulon aurolineatum, in the northern Gulf of Mexico and effects of the Deepwater Horizon oil spill. MS thesis, University of South Alabama, Mobile, AL

Nuttall MF, Johnston MA, Eckert RJ, Embesi JA, Hickerson EL (2014) Lionfish (Pterois volitans [Linnaeus, 1758] and $P$. miles [Bennett, 1828]) records within mesophotic depth ranges on natural banks in the Northwestern Gulf of Mexico. BioInvasion Rec 3:111-115

Patterson WF III, Dance MA, Addis DT (2009) Development of a remotely operated vehicle based methodology to estimate fish community structure at artificial reef sites in the northern Gulf of Mexico. Proc Gulf Caribb Fish Inst 61:263-270

Patterson WF III, Tarnecki JH, Addis DT, Barbieri LR (2014) Reef fish community structure at natural versus artificial reefs in the northern Gulf of Mexico. Proc Gulf Caribb Fish Inst 67:4-8

Pinheiro J, Bates D, DebRoy S, Sarkar D, R Core Team (2016) nlme: linear and nonlinear mixed effects models, http://CRAN.R-project.org/package=nlme http://CRAN. R-project.org/package $=$ nlme

R Core Team (2015) R: a language and environment for statistical computing. R Foundation for Statistical Computing, Vienna

Raymond WW, Albins MA, Pusack TJ (2015) Competitive interactions for shelter between invasive Pacific red lion-

Editorial responsibility: Mark Hixon,

Honolulu, Hawaii, USA (Guest Editor) fish and native Nassau grouper. Environ Biol Fishes 98: 57-65

Ruttenberg BI, Schofield PJ, Akins JL, Acosta A and others (2012) Rapid invasion of Indo-Pacific lionfishes (Pterois volitans and Pterois miles) in the Florida Keys, USA: evidence from multiple pre-and post-invasion data sets. Bull Mar Sci 88:1051-1059

Schmider E, Ziegler M, Danay E, Beyer L, Bühner M (2010) Is it really robust? Methodol Eur J Res Methods Behav Soc Sci 6:147-151

Schofield PJ (2009) Geographic extent and chronology of the invasion of non-native lionfish (Pterois volitans [Linnaeus 1758] and $P$. miles [Bennett 1828]) in the western North Atlantic and Caribbean Sea. Aquat Invasions 4:473-479

Schofield PJ (2010) Update on geographic spread of invasive lionfishes (Pterois volitans [Linnaeus, 1758] and P. miles [Bennett, 1828]) in the western North Atlantic Ocean, Caribbean Sea and Gulf of Mexico. Aquat Invasions 5: S117-S122

Schofield PJ, Akins L, Gregoire-Lucente DR, Pawlitz RJ (2014) Invasive lionfish use a diversity of habitats in Florida. US Geological Survey Fact Sheet 2014-3032

Stachowicz JJ, Fried H, Osman RW, Whitlatch RB (2002) Biodiversity, invasion resistance, and marine ecosystem function: reconciling pattern and process. Ecology 83: 2575-2590

Tamburello N, Côté IM (2015) Movement ecology of IndoPacific lionfish on Caribbean coral reefs and its implications for invasion dynamics. Biol Invasions 17:1639-1653

Tarnecki JH, Patterson WF III (2015) Changes in red snapper, Lutjanus campechanus, diet and trophic ecology in the northern Gulf of Mexico following the Deepwater Horizon oil spill. Mar Coast Fish 7:135-147

Whitehead A, Dubansky B, Bodinier C, Garcia TI, Miles S, Pilley C, Raghunathan V (2012) Genomic and physiological footprint of the Deepwater Horizon oil spill on resident marsh fishes. Proc Natl Acad Sci USA 109: 20298-20302

> Whitfield PE, Gardner T, Vives SP, Gilligan MR, Courtenay WR, Ray GC, Hare JA (2002) Biological invasion of the Indo-Pacific lionfish Pterois volitans along the Atlantic coast of North America. Mar Ecol Prog Ser 235:289-297

Williams R, Gero S, Bejder L, Calambokidis J and others (2011) Underestimating the damage: interpreting cetacean carcass recoveries in the context of the Deepwater Horizon/BP incident. Conserv Lett 4:228-233

Zar JH (1999) Biostatistical analysis, 4th edn. Prentice Hall, Englewood Cliffs, NJ

Submitted: January 18, 2015; Accepted: September 18, 2016 Proofs received from author(s): October 11, 2016 